\title{
Secondary Metabolites Found among the Species Trattinnickia rhoifolia Willd
}

\author{
Agerdânio Andrade de Souza 1,2,3, Brenda Lorena Sánchez Ortíz ${ }^{3}$, Rosemary de Carvalho Rocha Koga ${ }^{1,3}$, Priscila \\ Faimann Sales ${ }^{1,3}$, Divino Bruno da Cunha ${ }^{4}$, Ana Luiza Mantovaneli Guerra ${ }^{5}$, Gisele Custódio de Souza ${ }^{1,3}$ (D) \\ and José Carlos Tavares Carvalho $1,3,5, *$ (D)
}

check for
updates

Citation: de Souza, A.A.; Ortíz, B.L.S.; de Carvalho Rocha Koga, R.; Sales, P.F.; da Cunha, D.B.; Guerra, A.L.M.; de Souza, G.C.; Carvalho, J.C.T. Secondary Metabolites Found among the Species Trattinnickia rhoifolia Willd. Molecules 2021, 26, 7661. https://doi.org/10.3390/ molecules26247661

Academic Editor: John C. D'Auria

Received: 23 October 2021

Accepted: 9 December 2021

Published: 17 December 2021

Publisher's Note: MDPI stays neutral with regard to jurisdictional claims in published maps and institutional affiliations.

Copyright: (c) 2021 by the authors. Licensee MDPI, Basel, Switzerland. This article is an open access article distributed under the terms and conditions of the Creative Commons Attribution (CC BY) license (https:/ / creativecommons.org/licenses/by/ $4.0 /)$.
1 Post-Graduate Program in Pharmaceutical Innovation, Pharmacy Course, Department of Biological and Health Sciences, Federal University of Amapá, Rodovia Juscelino Kubitschek, km 02, Macapá CEP 68903-419, Amapá, Brazil; agerdanio.souza@unifap.br (A.A.d.S.); rosemarykoga@gmail.com (R.d.C.R.K.); pfaimann@gmail.com (P.F.S.); custodio_gisele@yahoo.com.br (G.C.d.S.)

2 Indigenous Intercultural Licensing Course, Binational Campus, Federal University of Amapá, Rodovia BR 156, n 3051, Universidade, Oiapoque CEP 68980-000, Amapá, Brazil

3 Research Laboratory of Drugs, Department of Biological and Health Sciences, Federal University of Amapá, Rodovia Juscelino Kubitschek, km 02, Macapá CEP 68903-419, Amapá, Brazil; charmed1797@gmail.com

4 Department of Biological and Health Sciences s/n, Institute of Xingu Studies, Federal University of Southern and Southeastern Pará, Centro, São Félix do Xingu CEP 68380-000, Pará, Brazil;

divinobruno@unifesspa.edu.br

5 Veterinary Medicine Course, Center of Rural Sciences, Federal University of Santa Maria, Avenida Roraima, 1000, Camobi, Santa Maria CEP 97105-900, Rio Grande do Sul, Brazil; serioususerana@gmail.com

* Correspondence: farmacos@unifap.br

Abstract: Plant-derived products may represent promising strategies in the treatment of Neglected Tropical Diseases (NTDs). From this perspective, it is observed that the Amazon phytogeographic region contains the tribe Canarieae of the Burseraceae family, composed of trees and shrubs supplied with resin channels. Its uses in folk medicine are related to aromatic properties, which have numerous medicinal applications and are present in reports from traditional peoples, sometimes as the only therapeutic resource. Despite its economic and pharmacological importance in the region, and although the family is distributed in all tropical and subtropical regions of the world, most of the scientific information available is limited to Asian and African species. Therefore, the present work aimed to review the secondary metabolites with possible pharmacological potential of the species Trattinnickia rhoifolia Willd, popularly known as "Breu sucuruba". To this end, an identification key was created for chemical compounds with greater occurrence in the literature of the genus Trattinnickia. The most evident therapeutic activities in the consulted studies were antimicrobial, antioxidant, anti-inflammatory, antiviral, antifungal, anesthetic and antiparasitic. An expressive chemical and pharmacological relevance of the species was identified, although its potential is insufficiently explored, mainly in the face of the NTDs present in the Brazilian Amazon.

Keywords: Burseraceae; pharmacology; phytochemistry; review; Trattinnickia

\section{Introduction}

Over the years, natural products have been used as raw material sources in the synthesis of chemical compounds that result in new drugs, a good part of which are used in the treatment of Neglected Tropical Diseases (NTDs) [1]. That is where the drugs in clinical use come from, corresponding to $40 \%$ of the drugs currently available, which are directly or indirectly derived from natural sources in the rainforest [2]. In this sense, Brazilian biodiversity is considered an extremely rich source of bioactive substances, highly diversified in innovative chemical structures [3], that dictate the planning of new chemical syntheses. 
In parallel to the biological variety found in the Amazon Forest, there are NTDs that encompass a group of 17 common infectious diseases in the region, including dengue, rabies, trachoma, buruli ulcer, endemic treponematosis, Hansen's disease (leprosy), American trypanosomiasis, African trypanosomiasis, cysticercosis, dracunculiasis, echinococcosis, foodborne trematode infection, lymphatic filariasis, onchocerciasis, schistosomiasis and soil-borne helminth infection, as well as leishmaniasis. Public health problems are also included, such as the human immunodeficiency virus (HIV) — which causes the acquired immunodeficiency syndrome (AIDS) - tuberculosis, malaria and other neglected infections. Thus, it is a heterogeneous group of diseases with serious social consequences, due to their high capacity for morbidity.

NTDs affect more than one billion people worldwide, with greater severity in individuals submitted to socioeconomic vulnerability, generally belonging to underdeveloped or emerging countries. As a result, social, public health, productivity and life quality problems are intensified, particularly among marginalized populations. Amid the secondary factors related to the persistence of NTDs, the following stand out: (a) gaps in science and research, for presenting insufficient knowledge, non-related to these diseases, (b) market factors, such as high-cost drugs, in existing or developing vaccines, and (c) gaps in public health, represented by poor access to medicines and treatments as a consequence of failures in administrative planning, even when such services are offered for free [4].

From this perspective, NTDs represent an enormous challenge for Brazil and other nations, since they are considered the infections with the highest levels of occurrencesuch as cutaneous or visceral leishmaniases, whether endemic or not. These diseases are heightened by their multiple forms of clinical manifestations, which depend on the pathogenicity of the infecting species. Its characteristics modalize leishmaniasis among its subclinical infections, with localized or disseminated microlesions, whether asymptomatic or not. In addition, wounds can spontaneously heal or progress from milder to more severe forms, which is why the WHO recommends priority treatment for this disease [1].

Leishmaniasis is considered an important public health problem in the world and is one of the six most important infectious and parasitic diseases of NTDs, with an annual incidence of 2 million cases of different clinical forms, representing a risk to 350 million people in developing countries [1,2].

Leishmaniases are diseases caused by the protozoan of the genus Leishmania that are marked by great clinical pleomorphism. The parasites that cause them are included in the subkingdom Protozoan, phylum Sarcomastigophara, order Kinetoplastida and family Trypanosomatidae, which are responsible for morbidity and mortality in several countries in tropical zones. Seven species that cause tegumentary leishmaniasis have already been identified in Brazil, six from the subgenus Viannia and one from the subgenus Leishmania. The three main species are: $L$. (V.) braziliensis, $L .(V$.$) guyanensis and L. (L.) amazonensis, and$ more recently, the species $L$. (V.) lainsoni, $L$. (V.) naiffi, L. (V.) lindenberg and $L$. (V.) shawi, identified in states in the North and Northeast regions [1].

Leishmaniases have factors that are increased by the virulence and dissemination of the protozoan, which depend on the host-parasite relationship. This is because the manifestation of the disease is not only correlated with the species of parasite involved, but also with the susceptibility of the host, assessed by its immune response [5]. Furthermore, the protozoan-susceptibility interaction is responsible for the strength of leishmaniasis, making it resistant to available therapeutic treatments, which are scarce and restricted to two lines: antimonials and non-antimonials. Likewise, the lack of a vaccine and the high toxicity rate of the treatment demonstrate the need for new antileishmanial drugs [6].

Due to the incipience of first-line medicines and considering the potential of the Amazon, research in the areas of phytochemistry and ethnopharmacology are increasingly important to expand knowledge in strategic areas related to Research, Development and Innovation (RD and I) about traditional medicines. Hence, it is possible to create prototypes of promising new chemotherapeutic agents with anti-leishmanial activity, with minimized or non-existent side effects. 
Amid the promising Amazonian plants for such objectives, we highlight the species Trattinnickia rhoifolia (T. rhoifolia), an angiosperm tree present in the biogeographic region that comprises Central America that belongs to the Burceraceae family, of the Canarieae tribe $[7,8]$.

The species Trattinnickia rhoifolia is used by traditional peoples to cure sore throats and skin lacerations, as well as to treat and prevent tumors and leukemia. To this end, the most used parts of the plant are the trunk bark, resin and leaves [8].

For the genus Trattinnickia, studies have already been carried out on photochemical mapping in the bark of the species Trattinnickia peruviana, which indicated the presence of lichen xanthone and triterpenes. Furthermore, triterpenes and sesquiterpene lactones were isolated in the resin of the species Trattinnickia aspera [7-9]. Additionally, the compounds podocarpus-flavone A and biflavonoid were identified in the leaves of Trattinnickia glaziovii [7-9].

Regarding the species T. rhoifolia, the focus of this study, triterpenes, monoterpenes, amentoflavones, sterols and sesquiterpene lactones have already been identified in different parts of the plant, such as resin, leaves and in the bark of its trunk [10,11].

It is important to present the phytochemical mapping of the species Trattinnickia rhoifolia Willd and consequently of the genus Trattinnickia, which is a promising source for obtaining biopharmaceuticals from the production of secondary plant metabolites and, as a result, represents an opportunity in the field of drug innovation. For this reason, it is essential to know the research that addresses its main characteristics, such as taxonomic, ethnopharmacological and phytochemical studies, in order to direct future biological tests based on the bioactive action of the species Trattinnickia rhoifolia Willd.

In this sense, this study constitutes, methodologically, an analytical bibliographical review related to the mapping of secondary metabolites found in the genus Trattinnickia and the studies on their pharmacological potential. Data collection was carried out from September 2020 to May 2021, using the following databases: CAPES journals, PubMed, Science Direct from Elsevier, Wiley Online Library, Springer-Nature, Taylor and Francis, BMC, Hindawi, Scielo, ACS-American Chemical Society, and Google Scholar, as well as the scientific article and patent databases "The LENS" and "ORBIT Intelligence".

The inclusion criteria for this work were: original articles and exclusive dissertations of the genus and species studied, with full text available in Portuguese, English or other languages. Exclusion criteria were: abstracts, online sites without scientific sources, incomplete texts, unrelated and repeated articles.

As for the search strategy, the descriptive words used in this work were: family Burseraceae, genus Trattinnickia and species Trattinnickia rhoifolia Willd, correlated with secondary metabolites and their pharmacological potential. The articles were selected by reading the titles and abstracts of publications, associated with the Boolean descriptor "AND", in order to refine the samples.

Therefore, the innovation present in this study consists in elucidating the potential use of the species Trattinnickia rhoifolia Willd, mainly due to reports of the use of the resin, bark and leaves of the plant by traditional peoples of the Amazon Region and, in this sense, assisting future studies that seek to understand and perform the chemical mapping of that species, highlighting its high pharmacological potential.

Hence, the review contributes to direct future studies that also prove the importance of evaluating the biological activities of the species Trattinnickia rhoifolia and address the scarcity of studies on the classes of metabolites present in the studied species, which comes from the Burseraceae family.

\section{Taxonomy of the Burseraceae Family}

The Burseraceae family has 19 genera and more than 700 species [7,8], composed of trees and shrubs. This group of plants, distributed in tropical and subtropical regions, is characterized by the production of aromatic oleoresins. More recently, APG IV 2016 performed an update on the taxonomic status of these angiosperm plants, recognizing 
several new orders. Among them, the following stand out: Boraginales, Dilleniales, Icacinales, Metteniusiales and Vahliales. Besides, this system suggests the inclusion of Burseraceae in the order Sapindales, class Dicotiledoneae and subclass Rosidae (APG IV 2016) [7].

Of the 19 genera of Burseraceae distributed in South America, only 6 are native (Bursera, Crepidospermum, Hemicrepidospermum, Paraprotium, Tetragastris and Trattinickia). In their turn, the other two (Dacriodes and Protium) were introduced and are representative in the Amazon Region [9]. One of the most expressive properties of Burseraceae is the natural production of aromatic oleoresins, which are used regionally in alternative medicinal treatments and in the ethnopharmacology of Amazonian traditional peoples. The plant genera Dacryodes and Protium are popularly known as: "almescla", "breu-branco", "breupreto", “breu-vermelho", “breu-terra", "breu-limão", “ breu-manga", “caraña”, “copal”, "copal-ouro", "copal-negro", "elemi", "manila-elemi", "frankincenso", "gugul", "maaliol", "mirra" and "okume" [10-12].

\section{Chemical Characteristics of Burseraceae}

The mapping of the chemical compounds of the Burseraceae family is concentrated in the oil-gum-resin, from which fractions considered volatile are usually obtained $[9,12]$. In principle, the volatilization of aromatic compounds in the exudate is responsible for the yellowish appearance and viscous liquid, which occurs because of the natural oxidation process (oxidized eudesmane). During deposition on the surface of the trunks, the resin acquires a grayish color and a greater degree of ductility - that is, it becomes more resistant $[12,13]$.

The manipulation of the resin is historically common among the traditional peoples of the Amazon, who use it in the manufacture of varnishes and paints, along with boatcaulking. The aromatic constituents that are present in the resin, bark and branches of the plant are widely used through combustion, as well as for lighting the homes of traditional Amazonian peoples, as repellents for undesirable insects and also in religious rituals [9-13]. Concerning food, the family has species that produce almonds-some with edible mesocarp, which represent sources of light fatty oil and have a pleasant taste. Its fruits contain $10 \%$ more sugar and produce $25 \%$ of this oil, indicated as a substitute for olive oil $[13,14]$.

The chemical characterization studies of the Burseraceae family focus on the constituents present in its leaves, of which the monoterpenes represent the dominant class of compounds, distributed in limonene, $\alpha$-phellandrene, $p$-cimene and their monocyclic derivatives. Aldehydes, ketones and acids are also present, though less frequently [14,15]. In pharmaceutical correlation, studies relevant to this class of compounds are involved in anti-acaricide, anti-inflammatory, anti-leishmania and antiviral activities [12,13]. There are studies in the literature with bicyclic monoterpenes such as thujan, pinane and canphane, which are associated with antifungal activity against Cryptococcus neoformans var. Neoformans - a systemic human fungus of high prevalence in immunosuppressive patients $[13,16]$.

There are similar chemical profiles that identify over 30 sesquiterpenes in the Burseraceae family. The most common and complex are in the genera Canarium and Commiphora, except in the species Boswellia carterii. In those cases, cadinene is isolated in essential oils obtained from the leaves, as the substance is found in lower concentrations in other parts of some species of this family [15,16]. From the genus Canarium, the elemol group was also isolated, which constitutes the synthesis of germacra (10), 4 diene, widely used to combat Phlebotomus-the genus to which the agents that transmit malaria and leishmaniasis belong $[13,17,18]$. This justifies the traditional use of the resin as a repellent.

On the other hand, essential oils from Protium leaves are rich in cariophilia, which is generally ubiquitous, and in sesquiterpenes, described as bactericides for the etiological agents that cause acquired respiratory infections, such as otitis, sinusitis and pneumonia [17-19]. Some sesquiterpenes such as cubebenol and $\beta$-Cubebene, involved in the mechanisms of inflammatory and immune responses, have also been isolated from Burseraceae $[18,20]$. 
In studies related to the tribe Canarieae, isolations of furanosesquiterpenes are described, which are furanogermacrane skeletons, forming 2-acetyl-8-12-epoxygermacra-1, (10), 4,7,11 tetraene and 2-methyl-8-12-epoxygermacra-1, (10) 4,7,11-tetraene. It is noteworthy that the active ingredients of these molecules are sources used in the composition of antimalarials $[13,18,19]$, which is why they are considered the most promising class of compounds for immunomodulatory activities. Regarding antitumor substances, we can mention the example of the diterpenoid taxol, which has already been applied in the treatment of breast and uterine cancer, with less invasive results in immunocompromised patients $[14,18,20]$.

In Burseraceae resins, the existence of tetracyclic and pentacyclic triterpenes is identified. These compounds are responsible for important characteristics, such as oxidation, due to the presence of tetracyclic tirucallane in the C-17 side chain, which is found as elemolic acid. In the scientific literature, the anti-inflammatory activity and the inhibition of the production of nitric oxide are also reported, in addition to in vitro antitumor activity $[14,19,20]$. This class of compounds was isolated from Canarium schweinfurthii and Dacriodes eludis, species of the tribe Canarieae, in which the study related to the respective compounds proved the existence of anti-inflammatory, antimicrobial, antiplasmodic, antiulcerogenic, anticariogenic, antiviral, anti-HIV, hepatoprotective, cardioprotective and analgesic activities [14,21-23].

In their turn, flavonoids are essential in plant systematics, but there were few technicalscientific reports found about these compounds in Burseraceae. Kaempferol, quercetin and their respective derivatives were identified in Protium and Commiphora [15-24]. There are, consequently, few reports related to the identification of coumarin in Burseraceae. However, coumarinolignoids and propacin have already been identified and isolated from Protium opacum - compounds that have hepatoprotective, immunomodulatory and anticancer activities $[14,25,26]$. Among medical reports, the healing and anti-inflammatory activities of the leaves of the species Protium helio and P. icicariba stand out [27].

Chemical research on the stem of the botanical family Burseraceae focuses mainly on pentacyclic triterpenes. The most abundant are the $\alpha$-amyrin and $\beta$-amyrin isomers [28], which have anti-inflammatory, antinociceptive, gastroprotective, hepatoprotective and antipruritic pharmacological activities, among others, [11,13,20], with recognized low toxicity $[20,29]$.

The studies carried out using stems, branches and bark of the species P. robustum, P. trifoliatum, P. nitidifolium and P. subserratum, collected in the Amazon region, identified sesquiterpenes in a higher percentage, as well as the following compounds: spatulenol, caryophyllene oxide, Khusimone, $\alpha$-copaen-4-ol, and in smaller amounts, $\alpha$-cubeben, $\alpha$ copaene, trans-caryophyllene, $\alpha$-trans-bergamothene, $\gamma$-muurolene, $\alpha$-muurolene, $\gamma$-cadinene $[14,20], \alpha$-calakorene, spathulenol, caryophyllene oxide, $\beta$-copaen- 4 - $\alpha$-ol, khusimone, 1-epi-cubenol, $\gamma$-eudesmol and $\alpha$-muurolol, with eighteen sesquiterpenes having the highest percentage of hydrocarbon sesquiterpenes (35.97\%): $\alpha$-cubeben, $\alpha$ copaene, $\beta$-cubeben, trans-caryophyllene, $\alpha$-elemene, $\alpha$-gurjunene, germacrene $D, \alpha$ - and $\beta$-selinene, cis-calamenene, trans-calamenene and cadalene $[14,20,28,29]$. The other sesquiterpenes are oxygenated, totaling $24.20 \%$ of the essential oil composition $[20,28,29]$.

The literature also describes the presence of aromatic compounds such as coumarins, phenylpropanoids, flavonoids and, to a greater extent, lignans, which demonstrates the biological potential of the family $[11,18]$. There are few reports related to the identification of coumarins in Burseraceae, but coumarinolignoid and propacin have already been identified and isolated from the species Protium opacum [18].

\section{Characteristics of the Species Trattinnickia Rhoifolia Willd}

The species Trattinnickia rhoifolia Willd is popularly known in the Amazon region as "Breu sucuruba". Its native origin is not endemic to Brazil, but T. rhoifolia Willd has an Amazon phytogeographic occurrence $[8,9,30]$. The studied group belongs to the kingdom Plantae, phylum Tracheophyta, class Magnoliopsida, order Sapindales, family Burseraceae, genus 
Trattinnickia and species Trattinnickia rhoifolia, which has wide ethnopharmacological use by indigenous peoples (Figure 1) [8,9,18,31].

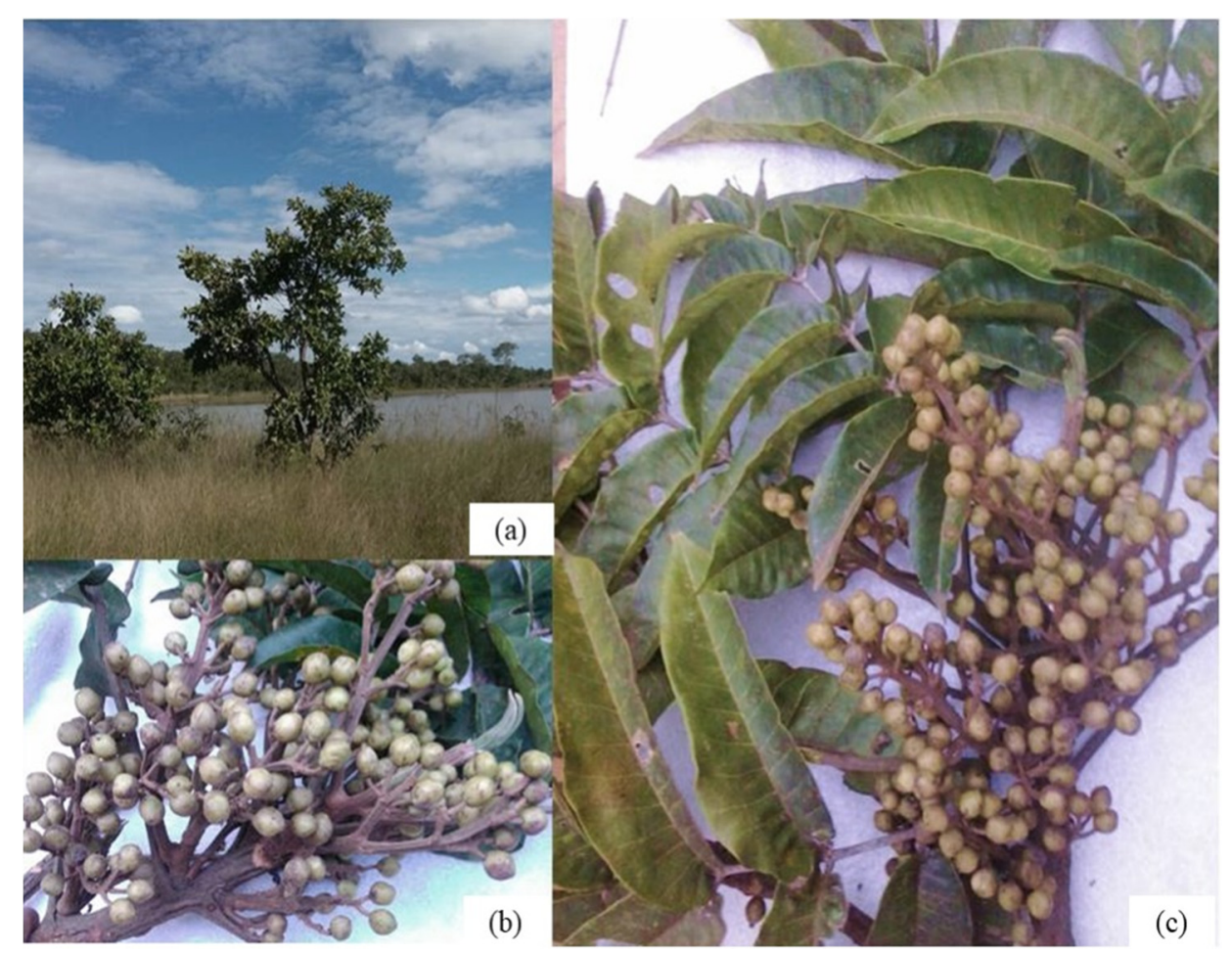

Figure 1. Photo: (a) shrub of Trattinnickia rhoifolia, (b) seeds and (c) alternate compound leaves.

The species Trattinnickia rhoifolia Willd is characterized by $32 \mathrm{~m}$ tall trees with $1.00 \mathrm{~m}$ DBH (diameter at $1.30 \mathrm{~m}$ from the ground), digitized base and cylindrical shaft. In addition, it has a grayish rhytidome with depressions and detachment in small woody plaques, which leave light streaks, lenticels are present, $2 \mathrm{~mm}$ thick dead brown skin and $1 \mathrm{~cm}$ thick bright orange skin. Orange sapwood has transparent exudation with a "breu" smell $[10,12,18]$.

The distribution of the aromatic resin present in the species Trattinnickia rhoifolia Willd is more predominant in the upper parts of the species, so that only the aromas attributed to the presence of terpenes are uniform. Due to this characteristic, the resin is used to combat some species of insects from the Psicodidae and Culicidae families. As a result of this practice, there is a reduction in the prevalence of malaria and leishmaniasis in indigenous villages and riverside communities $[8,9,30,32,33]$. For this reason, species of the genus Trattinnickia are widely known in the Amazon region by popular medicine as repellent, analgesic, anti-inflammatory, expectorant and healing plants $[11,13,20,34]$.

Nonetheless, scientific research that demonstrates its performance is incipient or almost non-existent, as illustrated by the scarcity of studies on the action mechanisms of species of the genus Trattinnickia in parasitic diseases such as leishmaniasis [33].

\section{Potential Use of the Species Trattinnickia rhoifolia}

The Burseraceae family has extensive chemical mapping and demonstration of its pharmacological properties, proven by its anti-inflammatory, antimicrobial, antiparasitic and antifungal activities. However, there are few studies regarding the identification of compounds for the genus Trattinnickia (Table 1) [17,34,35]. Likewise, focused research and phytochemical mapping of the species Trattinnickia rhoifolia Willd are scarce, although it is widely used in Amazonian folk medicine for the treatment of several diseases, including leishmaniasis, due to its synergistic, analgesic, anti-inflammatory and curative effects $[35,36]$. 
Table 1. Secondary metabolites found among the species Trattinnickia rhoifolia and their respective pharmacological activities.

\begin{tabular}{|c|c|c|}
\hline Parts Used & Isolated or Characterized Constituents & Pharmacological Activities \\
\hline Aerial & $\begin{array}{l}\text { Sesquiterpenes: } \alpha \text {-selinene }(1), \beta \text {-selinene (2), } \beta \text {-bisabolene (3) } \\
\text { Monocyclic sesquiterpene: } \alpha \text {-humulene (4) } \\
\text { Bicyclic sesquiterpene: } \beta \text {-caryophyllene (5) }\end{array}$ & $\begin{array}{l}\text { Anti-inflammatory, analgesic, anti-edemic, bactericide and } \\
\text { insecticide }[20,35,37-39]\end{array}$ \\
\hline Aerial oil-resin & Sesquiterpenes: $\beta$-bisabolene (3) & $\begin{array}{l}\text { Fungicidal and antimicrobial tests show efficacy against } \\
\text { Staphylococcus aureus }[40,41]\end{array}$ \\
\hline Aerial leaves & $\begin{array}{l}\text { Linear alkane: Eicosane }(\mathbf{6}) \text {; nonacosane }(7) \\
\text { Alkane: octadecane }(8), \text { octacosane }(9), \text { nonacosane }(7), \\
\text { tetrapentacontane }(\mathbf{1 0})\end{array}$ & $\begin{array}{l}\text { Antiparasitic against strays of Leishmania maior, L. donovani, } \\
\text { Trypanossoma brucei, cytotoxic activity against various types of tumor } \\
\text { cells [33], healing [38,42], anti-inflammatory and analgesic, } \\
\text { anti-edemic, anti-inflammatory, bactericide and insecticide, } \\
\text { fungicide }[38,39] \text { and antimicrobial }[39,43]\end{array}$ \\
\hline Leaf & $\begin{array}{l}\text { Biflavonoid: amentoflavane (11), } \\
\text { Oxyphytosterols: } 5 \alpha, 6 \alpha \text { epoxy- } \beta \text {-sitosterol (12), } 5 \beta, 6 \beta \text {-epoxy-beta-sitosterol } \\
\text { (13) }\end{array}$ & $\begin{array}{l}\text { Indicative of inhibition of the adenosine receptors GABA-A and B, } \\
\text { 5-hydroxytryptamide, central benzodiazepine, forskolin and inositol } \\
\text { triphosphate, as well as MAO A and B enzymes [42]. Inhibition of } \\
\text { these enzymes results in an antidepressant response [39] }\end{array}$ \\
\hline Leaf & Biflavonoid: amentoflavone (11) & $\begin{array}{l}\text { Inhibitory activity of cAMP phosphodiesterase, }[39,41,44] \\
\text { antioxidant, antifungal and anti-inflammatory activities }[45,46] \text {, as } \\
\text { well as indicative anti-HIV activities }[39,47]\end{array}$ \\
\hline Leaf & $\begin{array}{l}\text { Fatty acids: pentadecanoic acid (28); nonadecanoic acid (29); } \\
\text { methyl-11,14,17-eicosatrienoate ester ( } 30)\end{array}$ & Antioxidant, antifungal and anti-inflammatory [48] \\
\hline Leaf & Sesquiterpenoid: biatractylolide (31) & $\begin{array}{l}\text { Anti-tumor and antioxidant, reduction of AChE activity, } \\
\text { improvement of brain and memory capacities [47] }\end{array}$ \\
\hline Resin & 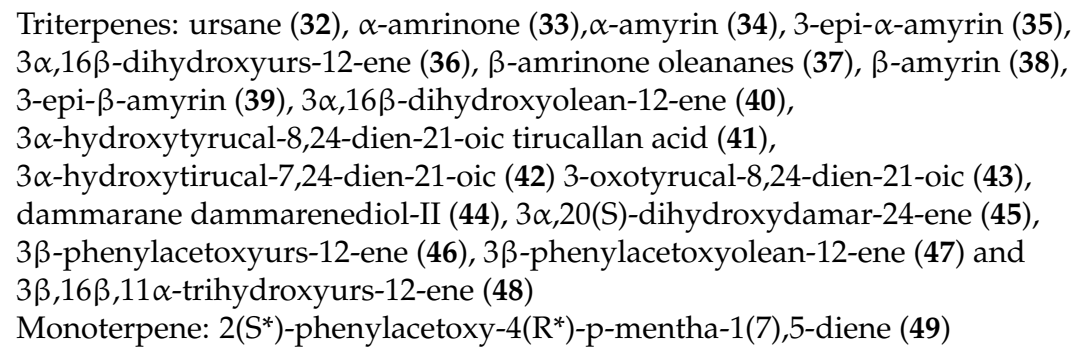 & $\begin{array}{l}\text { anticancer, anti-inflammatory, antileprotic, antiviral, antibacterial, } \\
\text { antifungal, antidiuretic, giardicide and inhibition of } \\
\text { acetylcholinesterase enzymes }[48,49]\end{array}$ \\
\hline
\end{tabular}


Table 1. Cont.

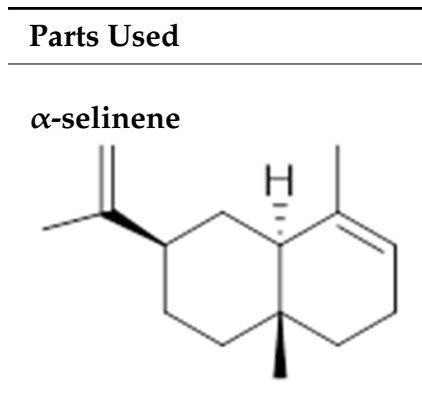

(1)

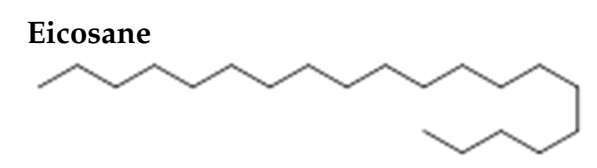

(6)

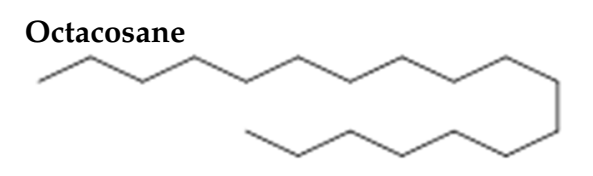

(9)

amentoflavone

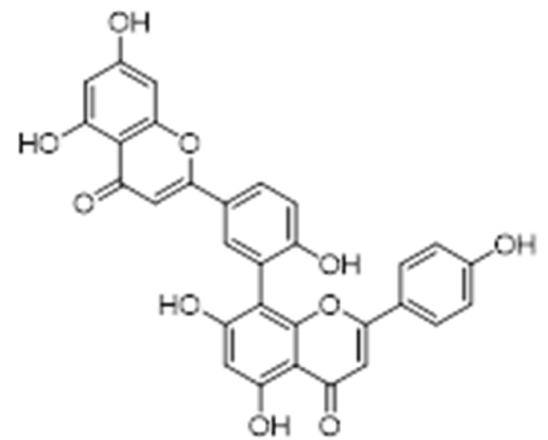

(11)

\section{Pharmacological Activities}

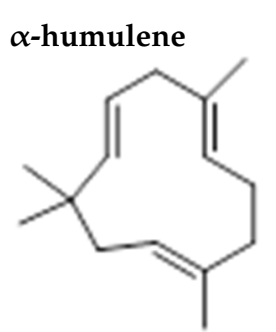

(4)

\section{Octadecane}

\section{Nonacosane}

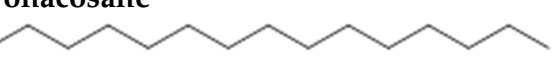

(7)

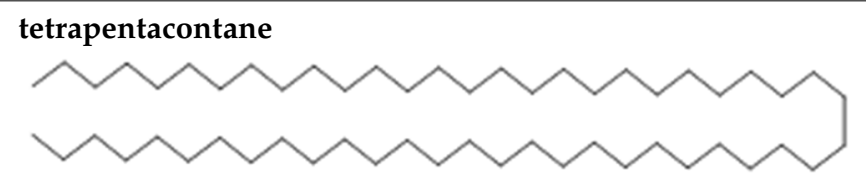

(10)
$5 a, 5 \alpha, 6 \alpha$ epoxy- $\beta$-sitosterol

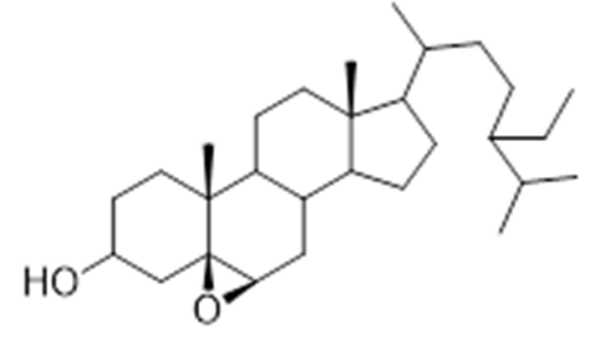

(12)
$5 \beta, 6 \beta$-epoxy-beta-sitosterol

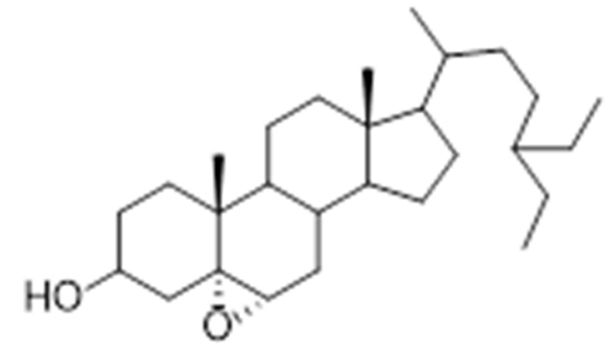

(13)

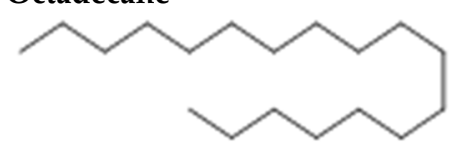

(8)

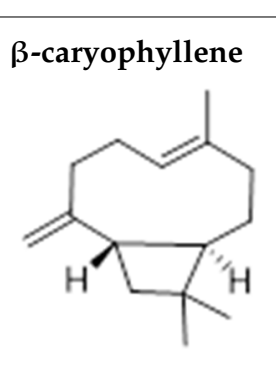

(5) 
Table 1. Cont.

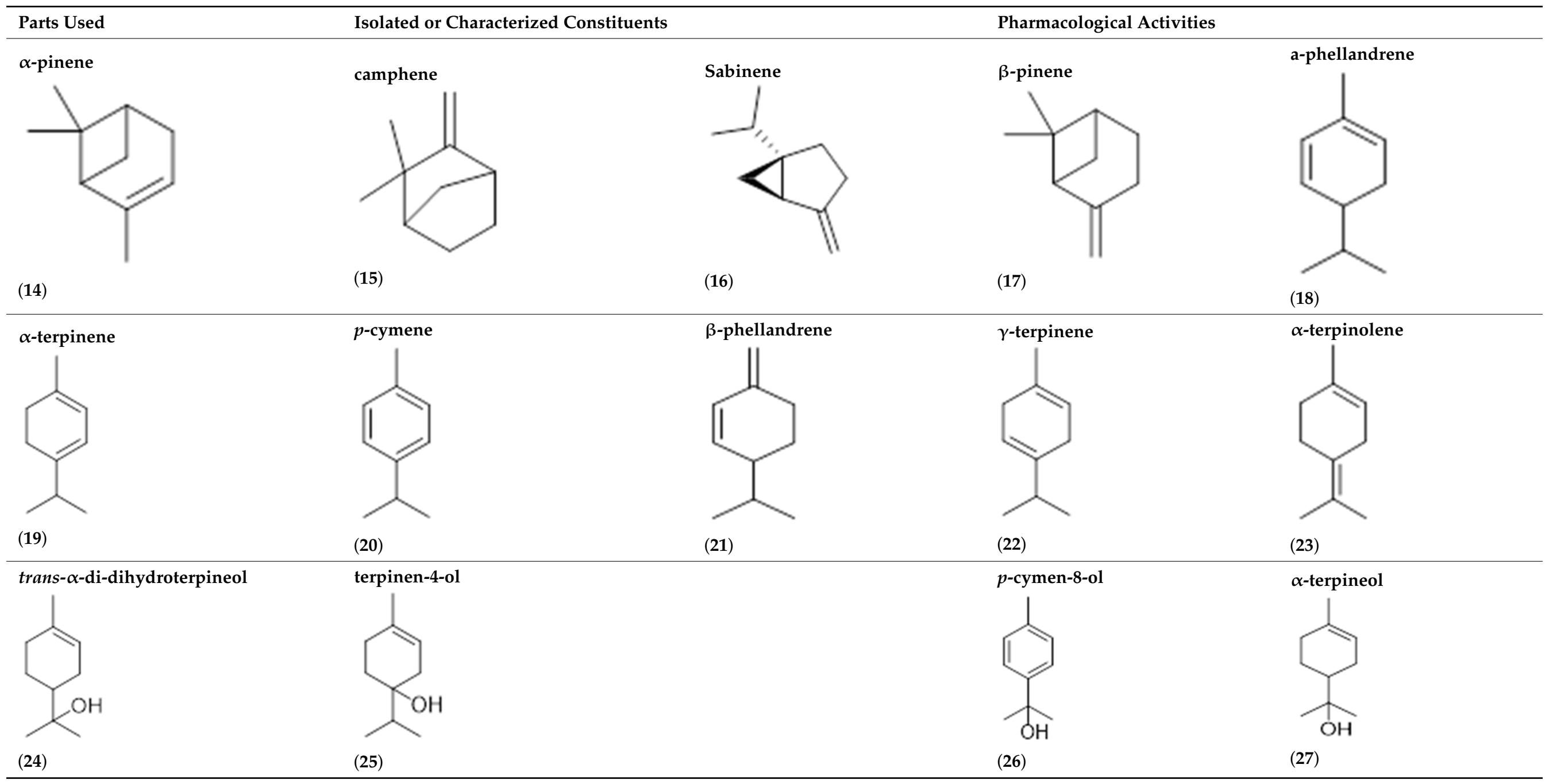


Table 1. Cont.

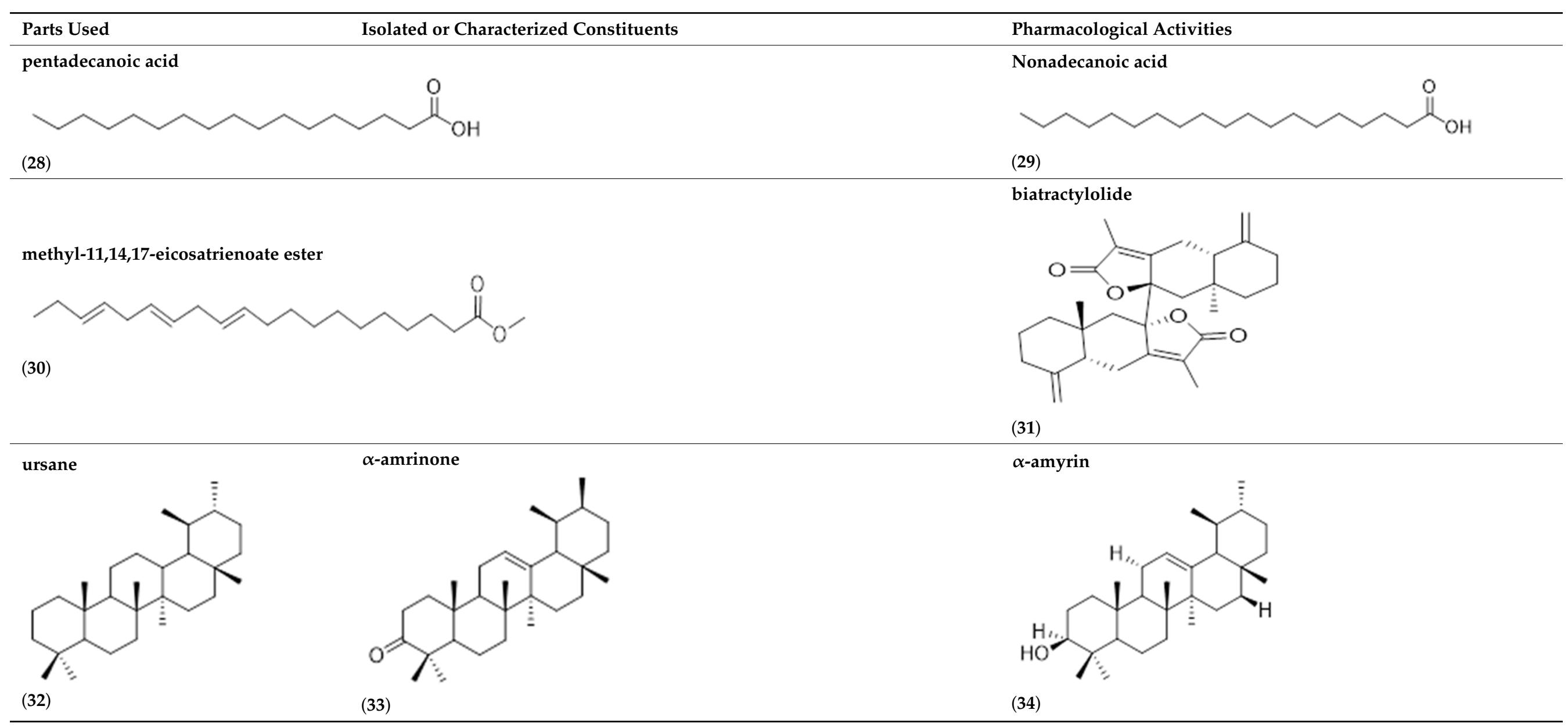


Table 1. Cont.

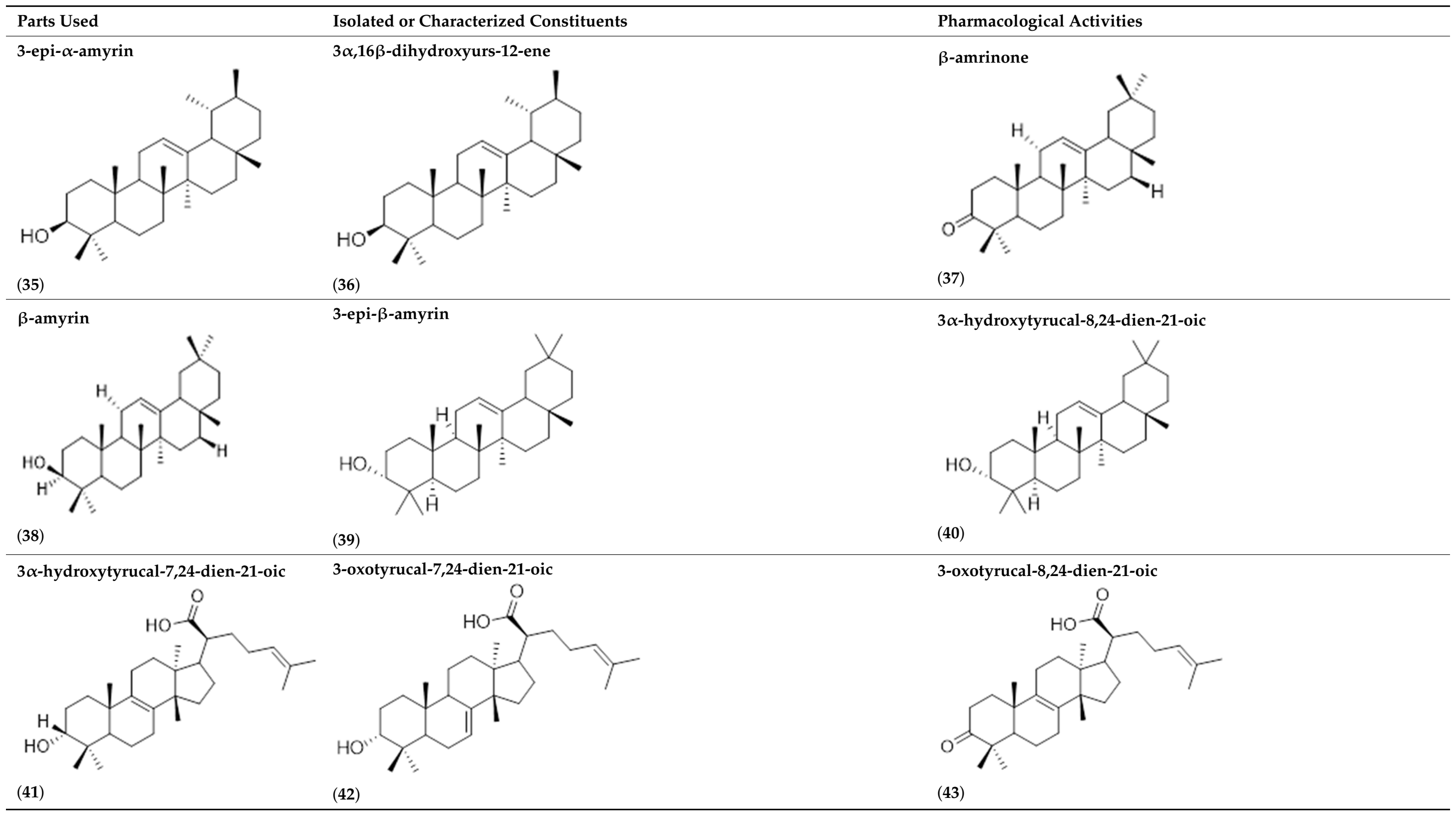


Table 1. Cont.

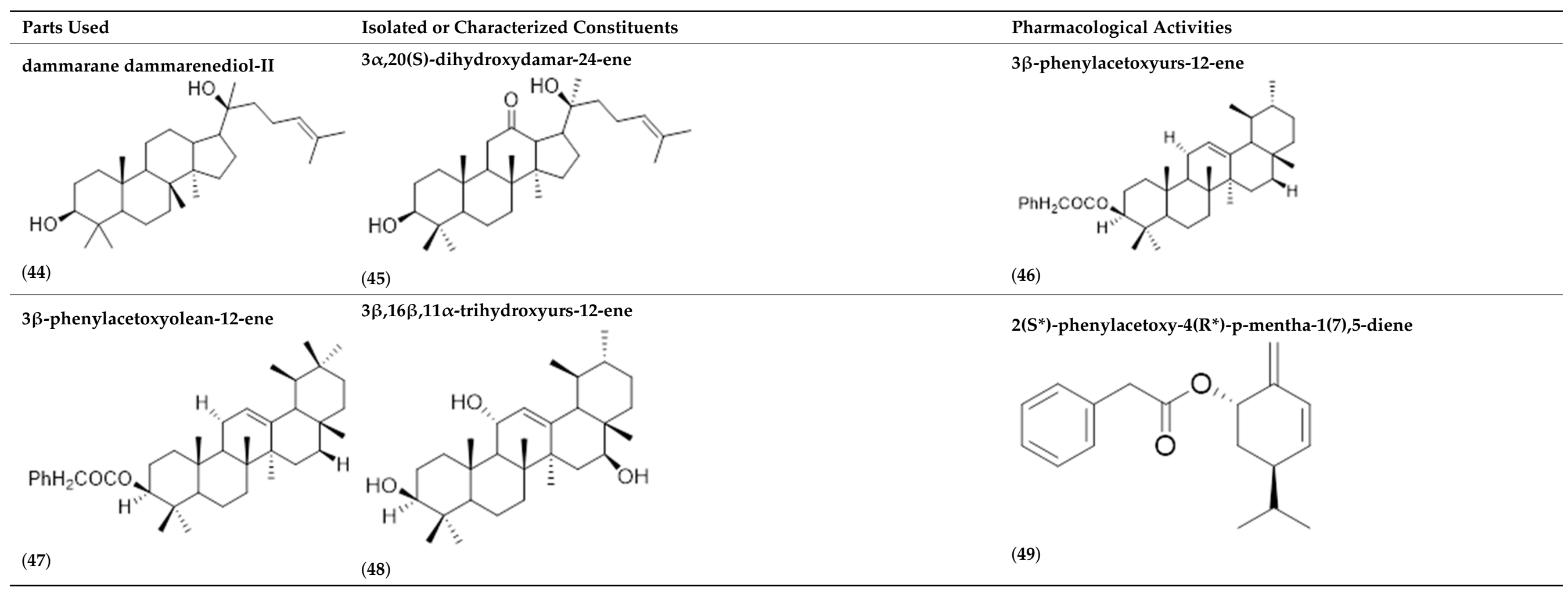


In the chemical composition of oil-resins of the species Trattinnickia rhoifolia, there is a predominance of sesquiterpenes, such as $\alpha$ - and $\beta$-selinene, $\beta$-caryophyllene, $\beta$-bisabolene and $\alpha$-humulene. The latter has anti-inflammatory and analgesic properties, while the penultimate is described in the literature as anti-edemic, anti-inflammatory, bactericidal and insect-repellent $[18,20,35,36,39]$.

Furthermore, other biological activities are reported on the species, related to treatments for leukemia and carcinomas [36,37], in addition to hepatoprotective activity [38]. Compounds isolated from T. rhoifolia Willd in Colombia showed mainly $\beta$-bisabolene [38,39] as a substance with strong fungicidal and antimicrobial powers, being efficacious against the bacteria Staphylococcus aureus [39], which is associated with several infections: from boils to septicemia (sepsis), including endocarditis (cardiac infections) and abscess [40-42]. Along with $\beta$-bisabolene, amentoflavone is also identified in the leaves of T. rhoifolia Willd and it is related to delay in cell degradation and aging, to anticancer activity and to other biofunctions.

In another study, T. rhoifolia presented $\beta$-sitosterol in in vitro tests, in which it was observed that pretreatment with the use of human breast cancer cells was able to inhibit cell invasion. Additionally, an in vivo test showed a reduction in the number and size of tumors in lymph node and lung metastases [43]. In the pharmacological activities of $\beta$-sitosterol, it is suggested to consume a dose of milk of $300 \mathrm{mg}$ to $5 \mathrm{~g}$ for lowering high cholesterol, so higher doses are indicated for symptoms related to prostatic hyperplasia [18].

Moreover, diterpene was found, a compound for which the activities are described in the literature as antiparasitic and antimicrobial (Figure 2).

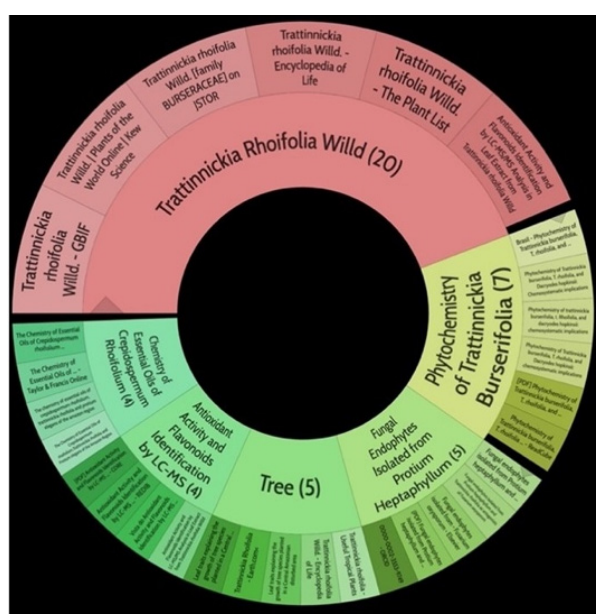

Figure 2. Pharmacological and phytochemical studies of the species Trattinnickia rhoifolia clustered by the Carrot $^{2}$ search engine in 2021.

Studies involving eicosane and nonacosane produced important antiparasitic effects against strains of Leishmania maior, L. donovani and Trypanosoma brucei, in addition to cytotoxic activity against several types of tumor cells [33,39]. In this context, it is important to report that research involving hydroalcoholic extracts from the leaves of Trattinnickia rhoifolia Willd showed stimulating activity in the treatment of cancer, with prevention of tumors and leukemia. Tests using leaf extracts produced with dichloromethane and acetone showed a moderate effect on the P388 leukemia cell in mice (experimental lymphocytic leukemia, originally induced in DBA/2 mice with methylcholanthrene) $[39,44]$.

In studies on extracts from the leaves of Trattinnickia rhoifolia, the existence of amentoflavan was identified, also found in oil-resins, $5 \alpha, 6 \alpha$ epoxy- $\beta$-sitosterol (IV) and $5 \beta$, $6 \beta$-epoxy- $\beta$-sitosterol (V) [14,46]. Besides, the researchers observed evidence of inhibition of the adenosine receptors GABA-A and B, 5-hydroxytryptamide, central benzodiazepine, 
forskolin, inositol triphosphate and MAO A and B enzymes, which results in an antidepressant response [39].

From this perspective, the authors have reported that amentoflavone acts in favor of the inhibitory activity of cAMP phosphodiesterase, among other enzymes. The process of inhibiting these mechanisms results in tissue regeneration $[39,45]$. Furthermore, it is possible to find experiments with amentoflavone linked to antioxidant, antifungal and antiinflammatory activities. Therefore, this molecule also represents a promising compound in anti-HIV activities, which establishes this species among the most promising in the phytochemical profile for new drugs $[39,46]$.

\section{Conclusions}

The extensive bibliographical research revealed that the genus Trattinnickia, which belongs to the Burseraceae family, represents an important ethnopharmacological source widely used by traditional peoples in the Brazilian Amazon due to its cultural and cosmological attributes in the treatment of Neglected Tropical Diseases, related to antiinflammatory processes and antiparasitic and repellent functions.

The reviewed scientific literature indicates that the biological activities of Trattinnickia rhoifolia are similar to the traditional use of the species, which associates the following properties to the "breu scuruba": anticancer, anti-inflammatory, antimicrobial, neurological and antiparasitic, all attributed to the phytochemistry of the genus.

The main classes of secondary metabolites, already characterized both in number of compounds and in pharmacological and environmental importance, are: alkaloids, terpenoids, sesquiterpenes, flavonoids, biflavonoids, oxyphytosterols and volatile oils. However, scientific support is restricted to mappings available for Asian and African genera, and studies on the subject are limited to these continents, even though the family is distributed in several tropical and subtropical regions of the world.

Although the results of this review are very promising for the use of the genus Trattinnickia as a multipurpose drug related to its pharmacological groups, there are several limitations in the current literature, especially with regard to studies for the species Trattinnickia rhoifolia Willd. On the other hand, popular knowledge bases are important to recognize that traditionally used extracts of the species Trattinnickia rhoifolia Willd can be effective not only when isolated or in direct use, but can also represent new and promising alternatives, with modulating effects when used in combination with other herbs or drugs.

Therefore, studying the species Trattinnickia rhoifolia Willd is essential for further work because of the importance of the results raised here, especially given the pharmacological potential of the group, which should be better explored-especially concerning the use of the species for its anti-inflammatory and analgesic activities, as reported by traditional communities in the Amazon region and presented in this article.

Author Contributions: Conceptualization, A.A.d.S. and B.L.S.O.; methodology, R.d.C.R.K., P.F.S. and A.A.d.S.; investigation, A.A.d.S.; data curation, D.B.d.C. and G.C.d.S.; writing-original draft preparation, A.A.d.S. and B.L.S.O.; writing-review and editing, A.L.M.G.; supervision, J.C.T.C.; project administration, J.C.T.C.; funding acquisition, J.C.T.C. All authors have read and agreed to the published version of the manuscript.

Funding: This research was funded by the Department of Research, Federal University of Amapá (No. 02/2021 DPq/PROPESPG/UNIFAP), Brazil, CAPES (1723/2018-00 PROCAD/AMAZONIA), and INCT North-Northeast Network of Phytoproducts-CNPq.

Institutional Review Board Statement: Not applicable.

Informed Consent Statement: Not applicable.

Data Availability Statement: Not applicable.

Conflicts of Interest: The authors declare no conflict of interest. 


\section{References}

1. Organização Mundial da Saúde (OMS). Doenças Tropicais Negligenciadas: Tratamento de Mais de um Bilhão de Pessoas em 2017. [atualizado em 2017 em 08 de setembro; citou 2017 em 9 de outubro]. Available online: http:/ /www.who.int/neglected_diseases / news / treating-morethan-one-billion-people-2017/en/ (accessed on 24 November 2021).

2. Bolzani, V.S.; Barreiro, E.J.; Viegas, J.R.C. Os produtos naturais e a química medicinal moderna. Q. Nova $2009,29,326-337$.

3. Kordali, S.; Cakir, A.; Ozer, H.; Cakmakci, R.; Kesdek, M.; Mete, E. Antifúngis, propriedades fitostoxixixixixicas e inseticidas de óleo essencial isolados dos acutidens origanum turcos e seus três componentes, carvacrol, timol e p-cymene. Tecnol. Bioresour. 2008, 99, 89-94.

4. Morel, C.M. Inovação em saúde e doenças negligenciadas. CSP 2006, 22, 1522-1523. [CrossRef]

5. Reis, L.C.; Brito, M.E.F.; Souza, M.A.; Pereira, V.R.A. Mecanismos imunológicos na resposta celular e humoral na leishmaniose tegumentar americana. J. Trop. Pathol. 2006, 35, 103-115. [CrossRef]

6. Gil, E.S.; Paula, J.R.; Nascimento, F.R.F.; Bezerra, J.C.B. Produtos naturais com potencial leishmanicida. Rev. Ciênc. Farm. Básica Apl. 2008, 29, 223-230.

7. Thulin, M.; Beier, B.A.; Razafimandimbison, S.G.; Banks, H.I. Ambilobea, um novo gênero de Madagascar, a posição de Aucoumea, e comenta sobre a classificação tribal da família incenso e mirra (Burseraceae). J. Nórdico Botânica. 2008, 26, $218-229$.

8. Souza, V.C.; Lorenzi, H. Botânica Sistemática; Instituto Plantarum de Estudos da Flora Ltd.: Nova Odessa, Bazil, 2005.

9. Noguera, B.; Díaz, E.; García, M.V.; SanFeliciano, A.; López-Perezc, J.L.; Israelb, A. Anti-inflammatory activity of leaf extract and fractions of Bursera simaruba (L.) Sarg (Burseraceae). J. Ethnopharmacol. 2004, 92, 129-133. [CrossRef]

10. Giraldo, M.C.R.; Susunaga, C.M.S. Atividade Antimicrobiana Presente em Partes Aéreas da Espécie Birsera Simaoruba e Graveolens de Birsera (Burseraceas) Contra Microrganismos Como: Tumefaciens Agrobacterium, Erwinia CAROTOVORA, Fusarium Oxysporum, Trichoderma Viride e Botry Cinetisrea. Doctoral Thesis, Universidade de Santa-fé de Bogotá, Bogotá, Colombia, 2000.

11. Rüdiger, A.L. Estudo Fitoquímico e Citotóxico de Oleorresinas de Burseraceae. Doctoral Thesis, Universidade Federal do Alagoas, Maceio, Brazil, 2012.

12. Langenheim, J.H. Resinas Vegetais: Química, Evolução, Ecologia e Etnobotânica; Timber Press: Cambridge, OR, USA, 2003.

13. Pereira, I.F.; Costa APFd Srbek-Araujo, A.C.; Guimarães, L.J.; Merencio, A.F.; Silva, A.G. A dispersão dos diásporos do protium icicariba (Burseraceae) um sistema em rede ou multifatorial? J. Chem. Ecol. 2020, 46, 163-175. [CrossRef] [PubMed]

14. Passero, L.F.; Laurenti, M.D.; Santos-Gomes, G.; Soares Campos, B.L.; Sartorelli, P.; Lago, J.H. Plants used in traditional medicine: Extracts and secondary metabolites exhibiting antileishmanial activity. Curr. Clin. Pharmacol. 2014, 9, 187-204. [CrossRef] [PubMed]

15. Duwiejua, M. Isolamento da picopoligramaina da resina de Bursera simaruba. Planta Med. 1993, 59, $10-35$.

16. Mesa, M.E.S.; Peñaranda, L.M.O. Avaliação da Atividade Antimicrobiana dos Extratos de Partes Aéreas da Espécie Bursera Simaruba e Bursera Graveolens, Contra Alguns Microrganismos Patogênicos. Ph.D. Thesis, Universidade de Bogotá, Bogotá, Colombia, 2003.

17. Khalid, S.A.; do Burseraceae, Q. (Eds.) Química e Taxonomia Química dos Rutales; Acadêmico: London, UK, 2003.

18. Rüdigera, A.L.S.; Siani, A.C.; Veiga, V. Plant revise a química e a farmacologia do gênero américa do Sul protium. f. (Burseraceae). Comentários Farmacogn. 2007, 1, 93-104.

19. Khalid, S.A. Química do Burseraceae. In Química e Taxonomia QuíMica dos Rutales; Waterman, P.G., do Grundon, M.F., Eds.; Acadêmico: London, UK, 1983; pp. 281-297.

20. Ortega, E.A.P. Contribuição Para o Estudo Fitoquímico de Bursera Simaruba (L.) Sarg. Ph.D. Thesis, Universidade de Bogotá, Bogotá, Colombia, 2002.

21. Braz Filho, R. Contribuição Fitoquímica para o Desenvolvimento de um País Emergente, Quim. Nova. 2020, 33, $229-239$.

22. Laffitte, E.; Revuz, J. Talidomida: Uma droga antiga com novas aplicações clínicas. Opinião Espec. Sobre Segurança Drog. 2000, 127, 603-613.

23. Aragão, G.F.; Carneiro, L.M.V.; Junior, A.P.F.; Vieira LCBandeira, P.N.; Lemos, T.L.G. Um possível mecanismo para efeitos antidepressivos de alfa e beta-amilina de Protium heptaphyllum (aubl.). Farmacol. Bioquímica E Comport. 2006, 85, $27-35$.

24. Melnikova, N.; Malygina, D.; Balakireva, A.; Peretyagin, P.; Revin, V.; Devyataeva, A.; Malafeeva, K.; Revin, V.O. Efeito de Difosfato de Betulin em Curativos de Feridas de NPs de Celulose Bacteriana-ZnO na Agregação de Plaquetas e a Atividade de Oxidoreductases Reguladas por NAD(P)+/NAD(P)H-Balance in Burns on Rats. Moléculas 2021, 26, 5478.

25. Camargo, J.R. Isolamento de Ingredientes Biologicamente Ativos Presentes em Espécies Colombianas da Família Burseraceae. Ph.D. Thesis, Pontifícia Universidade Javeriana, Bogotá, Colombia, 2000.

26. Alvarenga, R.F.; Silva, D.R.C.; Maria, E. Síntese de Indicuminas: Análise Retrossintética Para a Obtenção de Cumarinolignoides. In Anais do Congresso Fluminense de Inovação Tecnológica; UENF: Rio de Janeiro, Brazil, 2014.

27. Otuki, M.F.; Vieira-Lima, F.; Malheiros, A.; Yunes, R.A.; Calixto, J.B. Topical anti-inflammatory effects of the ether extract from Protium kleinii and $\alpha$-amyrin pentacyclic triterpene. Eur. J. Pharmacol. 2005, 507, 253-259. [CrossRef]

28. Siani, A.C.; Nakamura, M.J.; Tappin, M.R.R.; Monteiro, S.S.; Guimarães, A.C.; Ramos, M.F.S. Composição química da Burseraceae sul-americana não volátil oleoresins e avaliação preliminar de solubilidade de sua mistura comercial. Análises Fitoquímicas 2012, 23, 529-539. 
29. Oliveira, L.M.; Queiroz, D.P.K.; Melo, L.E.S.; Marques, M.O.M.; Facanali, R.; Lima, M.P. Constituintes voláteis dos galhos de quatro espécies de Protium Ocorrentes na Flora da Reserva Ducke, Sci. Amazon. 2018, 7, 68-73.

30. Do Brasil, F. Burseraceae in flora do Brasil 2020 em Construção; Jardim Botânico: Rio de Janeiro, Bazil, 2012.

31. Di Stasi, L.C.; Hiruma-Lima, C.A. Plantas Medicinais na Amazônia e na Mata Atlântica; Editora Universidade Estadual Paulista: São Paulo, Bazil, 2002.

32. Daly, D.C.; Melo, M.F. Quatro novas espécies de Trattinnickia da América do Sul. Estudos em Neotropical. Burseraceae XXII. Brittonia. 2017, 69, 1-11.

33. David, K.; Shirley, C. Phytosterols benefícios para a saúde e preocupações potenciais: Uma revisão. Pesqui. Nutr. 2005, $413-428$.

34. Júnior, F.P.; Araújo, V.F. Plantas da Amazônia para produção cosmética: Uma abordagem química 60 espécies do extrativismo florestal não-madeireiro da Amazônia/Floriano. Projeto Non-Wood II PD 31/99. Rev. Unb. Brasilia 2005, 2, 12-244.

35. Zoghbi, M.G.B.; Cunha, E.V.L.; Filho, W.W. Óleo essencial de Protium unifoliolatum (Burseraceae). Acta Amaz. 1993, $23,15-16$. [CrossRef]

36. Jing, Y.K.; Xia, L.J.; Chen, D.; Han, R.; Fan, Q.C.; Waxman, S. Boswellic acid acetate induz apoptose através de vias mediadas por caspase em células de leucemia mielóide. Ter. Do Câncer Molecular. 2005, 4, 381-388.

37. Salazar, U.J.; Porcar, R.C. Componentes químicos das folhas de Trattinickia rhoifolia, Av. En Química 2010, 5, $63-65$.

38. Oliveira, F.A.; Chaves, M.H.; Almeida, F.R.C.; Lima, R.C.P., Jr.; Silva, R.M.; Maia, J.L.; Brito, G.A.C.C.; Santos, F.A.; Rao, V.S Protective effect of $\alpha$-and $\beta$-amyrin, a triterpene mixture from Protium heptaphyllum (Aubl.) March. trunk wood resin, against acetaminophen-induced liver injury in mice. J. Etnopharmacolology 2005, 98, 103-108. [CrossRef] [PubMed]

39. Mendonça, D.E.; Onofre, S.B. Atividade antimicrobiana de resina de óleo produzida pela Copaiba Copaifera multijuga Hayne (Leguminosae), Rev Brasileira de Farmacognosia Braz. J. Pharmacogn. 2009, 19, 577-581.

40. Lorenzi, H.; Matos, A.F.J. Plantas Medicinas no Brasil: Nativas e Exóticas; Instituto Plantarum: Nova Odessa, Bazil, 2002.

41. Cervantes-García, E.; García-González, R.; Salazar-Schettino, P.M. Características gerais de Staphylococcus aureus. Rev. Lat. Patol. Clin. Med. Lab. 2014, 61, 28-40.

42. Ziech, R.E.; Farias, L.D.; Balzan, C.; Ziech, M.F.; Heinzmann, B.M.; Lameira, O.A. Atividade antimicrobiana do oleorresina de copaíba (Copaifera reticulata) frente a Staphylococcus coagulase positiva isolados de casos de otite em cães. Pesq. Vet. Bras 2013, 33, 909-913. [CrossRef]

43. Ogbe, R.J.; Ochalefu, D.O.; Mafulul, S.G.; Olaniru, O.B. A review on dietary phytosterols: Their occurrence, metabolism and health benefit. Asian. J. Plant Sci. Res. 2015, 5, 10-21.

44. Gutmann, H.; Bruggisser, R.; Schaffner, W.; Bugman, K.; Botomino, A.; Drewe, J. Transporte de amentoflavone através da barreira do cérebro de sangue in vitro. Planta Med. 2002, 68, 804-807. [CrossRef] [PubMed]

45. Saponara, R.; Bosisio, E. Inibição de adipocyte de rato cAMP phosphodiesterase por biflavonas de Ginkgo biloba L. J. Nat. Prod. 1998, 2, 98-100.

46. Banerjee, T.; Valacchi, G.; Ziboh, Z. Inibição da expressão ciclooxygenase-2 induzida pela TNFa por amentoflavone através da supressão da ativação NF-kB em células A549. Mol. Cell. Bioquímica 2002, 238, 5-10.

47. Zhu, L.; Ning, N.; Li, Y.; Zhang, Q.-F.; Xie, Y.-C.; Irshad, M.; Feng, X.; Tao, X.-J. Biatractylolide Modula PI3K-Akt-GSK3?-Caminhos dependentes para proteger contra danos celulares induzidos por glutamato nas células PC12 e SH-SY5Y. Med. Complementar Altern. Baseada Evid. 2017, 2007, 1291458.

48. Bandeira, P.N.; Lemos, T.L.C.; Sônia, M.O.C.; Santos, H.S. Obtenção de derivados da mistura triterpenoídica amirina. Braz. J. Pharmacogn. 2007, 17, 204-208. [CrossRef]

49. Mahato, S.B.; Nandy, A.K.; Roy, G. Triterpenóides. Fitoquímica 1992, 31, 2199-2249. 